\title{
THE INFLUENCE OF PROBLEM-BASED LEARNING COMMUNITIES ON RESEARCH LITERACY AND ACHIEVEMENT GoAL Motivation
}

\author{
Mary Gutman \\ Efrata College, Israel
}

\begin{abstract}
The current study investigates two Problem-Based Learning (PBL) processes that were carried out in two different Online Learning Communities of 62 pre-service teachers who took a Research Literacy course as a part of their academic obligation. The first one was combined with the moderator based learning scaffoldings $(O L C+M)$, and the other one with the social based learning scaffoldings $(O L C+S)$. The study seeks to map the differences between these two OLCs in terms of Achievement Goal Motivation and Research Literacy skills as a result of the PBL intervention, and the correlation between these aspects as is expressed in each group. The findings indicated that PBL had a significant positive effect on AGM in both groups, while only the OLC+S showed the significant outperforming in some of the Research Literacy skills, as well as the positive correlation between them and the Mastery Approach component of AGM. The discussion raises possible interpretations of theoretical and practical relationships between Research Literacy skills in the educational field and motivational factors among adult students, as they are expressed in online communication environments.
\end{abstract}

\section{KEYWORDS:}

Problem-Based Learning, Online Learning Community, Social Scaffoldings, Research Literacy, Achievement Goal Motivation

\section{INTRODUCTION}

The need to prepare pre-service teachers in implementing sophisticated teaching skills in their classrooms poses teacher educators against up-to-date challenges of implementation of appropriate training methods, which could leverage their inquiry-based pedagogical abilities (Lim, Chai \& Churchill, 2011; Gutman, 2017). Such abilities include identifying a pedagogical problem, planning and designing an inquiring process, gathering and interpreting data regarding student learning, behavior, motivation, and achievement in order to formulate and to consolidate their coping method, and finally, instilling them with the ability to unify and crystalize the demanded conclusions. All these proficiencies are syndicated under the term Research Literacy, which can be appropriately developed by the collaborative and cooperative learning environments that require learners to cope with professional challenges and problems (Barber, King, \& Buchanan, 2015; Gutman \& Genser, 2017; Savery, 2015; Leahy \& Twomey, 2005; Zhu \& Baylen, 2005). 
International Journal of Education (IJE) Vol.6, No.4, December 2018

\section{Problem-Based Learning and Achievement Goal Motivation}

Recent studies (Lim, Chai, \& Churchill, 2011; Leahy \& Twomey, 2005; Zhu \& Baylen, 2005) indicate that there is successful PBL adaptation to online learning communities. In this format, such collaborative learning heightens motivation and increases the feeling of connection to other learners. The current study focuses on the mastery and performance patterns of motivation, which define the Achievement Goal Motivation in the recent theoretical review (Elliot \& Chruch, 1997; Elliot \& McGregor, 2001; Elliot \& Murayama, 2008; Wolters, 2004; Duffy \& Azevedo, 2015). The researchers define two types of achievement goal perceptions. The first type refers to the students' ability to set learning goals and standards, and to manage their motivational strategies by striving for successful performances and academic excellence (mastery approach). The second type reflects the students' manner of competitiveness, which refers to outperforming their peers, demonstrating their mastery relative to classmates or trying to prove their performances publicly (performance approach). In a similar way, performance and mastery avoidance characterizes students who exert effort in order to avoid a lack of learning strategies or outcomes, as well as the failure of the learning processes or the results, compared with their peers.

\section{Learning-Based Scaffoldings}

The recent studies (Harun, Yusof, Jamaludin \& Hassan, 2012; Barber, King, \& Buchanan, 2015) classify PBL as a unique method of promoting students' engagement and motivation. Such an effect can be achieved in cases where the PBL is explicitly supported by learning-based scaffolding (e.g. milestones, promoting thinking questions and feedback), which occurs with the initiative of the moderator or participants with the option of sharing the solving process for the required problem (Daradoumis, Caballe, Perez \& Xhafa, 2012; Lee \& Tan, 2010).

This division distinguishes between the two kinds of the online communities, specifically in this study, these are the moderator- based or social- based scaffoldings. Moderator based scaffoldings which serve as a basis of most online learning communities, adheres to the concept that "the teacher is the center of knowledge". In such communities, the moderator bears the responsibility of sharing various ways of promoting thinking, determining the direction of learning, and setting the pace at all stages. Vis-à-vis, the other type of learning communities, which are based on social scaffolding, consist of a collaborative and cooperative perception, according to which students consider alternative explanations, problems or negotiate complex issues, to evaluate progress, and to systematically offer justifications for their reasoning (Palincsar, Anderson \& David, 1993).

According to the literature (Abdelaziz, 2014; Lee \& Tan, 2010; Hung \& Chen, 2001), the online discussions produce the desired outcomes if the moderator and participants demonstrate a high level of involvement. While moderators' role is to encourage participants by providing support in tackling any challenges, the participants' role is to engage in mutual exchange of knowledge and learning strategies, intellectual resources, and products. In this study, the main effort is to investigate and to characterize each type of scaffolding while looking at each one separately and in particular through two dedicated learning communities. In the current study this model of OLC, which combined social scaffoldings, is called OLC+S. Alternatively; the OLC that is coordinated and controlled by moderator only, is defined as OLC+M. 


\section{The Current Study}

The main goal of this study is to evaluate the influence of Problem-Based Learning on student awareness of the Research Literacy in their pedagogical practice and in their motivation to achieve their goals. In the current intervention process, pre-service teachers were asked to follow a problem-based learning process consisting of four stages. In the first stage, participants were required to define a research problem. Then they had to identify it in their teaching practice. In the third stage they were encouraged to formulate a suitable research question for the identified problem, and in the final stage, they designed an appropriate research process (Tuckman \& Harper, 2012, Gutman \& Genser, 2017). This process has occurred simultaneously in two OLCs. The first group was exposed to the moderator based scaffoldings, while the second group employed social scaffolding by providing mutual support in the learning community. In the present research, student performance and motivation in both online learning communities with different types of scaffoldings (moderator or social based scaffoldings) are compared in order to determine which kind of scaffoldings increase the proficiency in assimilating these issues. Additionally, the correlation between achievement goal motivation and the kind of scaffoldings were investigated.

\section{METHOD}

\section{Participants and Research Design}

This study was performed on 62 second-year pre-service teachers who took part in two 28-hour courses on Research Literacy in education as part of their academic obligation. Both courses were based on a similar learning program and an identical syllabus, they were instructed by the same lecturer, and they both combined the Online Learning Community (OLC), which took place in a discussion group environment.

A major requirement of the courses was to include and to share the PBL experiences. To achieve this aim the Online Learning Communities, which were designed to encourage students to share their own experiences of educational or pedagogical problems they actual dealt with in their teaching practice and with their classmates, helped to (a) define the appropriate "research problem" based on academic literature, $(b)$ identify a similar research problem as is expressed in their own teaching practice, (c) formulate different versions of the research question, and (d) design a suitable procedure (Gutman \& Genser, 2017). These Problem-Based Learning processes took place in online forums (named 'online community'), one of which was directed by a teacher and consisted of the moderator based scaffoldings $(\mathrm{OLC}+\mathrm{M})$, while the other was based on the social scaffolding only $(\mathrm{OLC}+\mathrm{S})$. While the OLC+M group focused on students' ability to initiate discussion as a response to the moderator's guidelines, the interaction in the $\mathrm{OLC}+\mathrm{S}$ group was defined as a cooperative learning environment where the students were encouraged to take part in the peers' topics by providing resources, materials and the expected products' examples.

The research questions of this study refer to the differences between the groups in their Achievement Goal Motivation and the Research Literacy skills, as an effect of the continuous participation in these two processes. Specifically, I seek to discover the correlation between the special natures of the interactions that were carried out in each group, and the above aspects, in order to emphasize the possible connection between different types of scaffolding, the motivational factors of a learning community and research literacy skills. 


\section{Measures}

The quantitative research method of this study included Achievement Goal Inventory (AGI), which consisted of student self-reports, and a Research Literacy Task (RLT), which reflected actual academic performance.

\section{Achievement Goal Inventory (AGI)}

The AGI (Elliot \& McGregor, 2001), customized to the needs of the present study, contains 12 five-point Likert-scale items, according to the four achievement goal dimensions: (a) masteryapproach, (b) mastery-avoidance, (c) performance-approach, and (d) performance-avoidance. The first set of items refers to the mastery/ performance factors, some of which were in respect to the achievement goal (e.g. "I am striving to understand the content of this course as thoroughly as possible"/ "I am striving to do well compared to other students"). The second set refers to the approach/avoidance scale with respect to the concerns regarding the understanding of the learning material, performances, and self-efficacy during the course (e.g. "I am striving to avoid learning less than I possibly could in this class"/ "My goal is to avoid performing worse than other students") (Duffy \& Azevedo, 2015; Adesope et al., 2015). Given the unique style of this research tool, AGI seems to be appropriate for measuring the different scales of motivation during the Problem-Based Learning, which is characterized as a multi-dimensional cognitive process that combines self-efficacy parameters alongside raising doubts and difficulties in making decisions (Savery, 2015; Harun et al., 2012).

\section{Research Literacy Task (RLT)}

This was an open-ended Research Literacy Task based on analyzing the chosen offered academic articles, which presented action studies, and then follow the model of defining the problem described therein, identifying a similar problem in their own pedagogical practice, formulating an appropriate research question and method, and explaining its value. This task was based on the students' Research Literacy skills, which were codified and evaluated based on the scoring scheme (Gutman \& Genser, 2017; Figure 1): Each item of this task, which was estimated according to the scale from 1 to 4 was meant to exhibit a degree of strength of link between Research Literacy and pedagogy. This link earned a grade of either 4 (conceptual and procedural arguments) or 3 (procedural arguments), or 2 (conceptual understanding) or 1 (procedural understanding).

\section{RESULTS}

\section{Achievement Goal Motivation}

The first research question seeks to determine the differences in Achievement Goal Motivation between the two groups $(\mathrm{OLC}+\mathrm{M}$ and $\mathrm{OLC}+\mathrm{S})$ as a result of Problem Based Learning intervention. In order to highlight the research interventions' impact on the AGM in each group, the repeated measures were performed and showed the significant increase in AGM for each component. Specifically, the OLC+M group improved in all four components of AGM: masteryapproach $(\mathrm{F}(1,30)=9.17, \mathrm{p}<0.01$, partial $\eta 2=0.23)$, mastery-avoidance $(\mathrm{F}(1,30)=12.27, \mathrm{p}<$ 0.01 , partial $\eta 2=0.29)$, mastery-avoidance $(F(1,30)=7.58, p<0.01$, partial $\eta 2=0.202)$, and 
performance-avoidance $(\mathrm{F}(1,30)=14.21, \mathrm{p}<0.001$, partial $\eta 2=0.321)$. The OLC+S also showed significant improvement on all of the repeated measures. Furthermore, students in the $\mathrm{OLC}+\mathrm{S}$ outperformed students in the OLC+M in all components of AGM: mastery-approach $(\mathrm{F}(1,30)=45.76, \mathrm{p}<0.001$, partial $\eta 2=0.58)$, mastery-avoidance $(\mathrm{F}(1,30)=58.78, \mathrm{p}<0.001$, partial $\eta 2=0.64)$, mastery-avoidance $(\mathrm{F}(1,30)=49.17, \mathrm{p}<0.001$, partial $\eta 2=0.60)$, and performance-avoidance $(\mathrm{F}(1,30)=62.01, \mathrm{p}<0.001$, partial $\eta 2=0.67)$. Table 1 presents the means and standard deviations for the AGM components (mastery-approach, performanceapproach, mastery-avoidance and performance-avoidance) by testing occasion (pre- and posttest).

\section{Research Literacy}

The second purpose of the study was to investigate the variance between the two groups on the Research Literacy skills after the PBL intervention. The One-way MANOVA test results indicate a significant overall difference between the groups for all four RL skills: $\mathrm{F}(4,60)=7.06 \boldsymbol{p}<.001$. In particular, significant differences with favor to the $\mathrm{OLC}+\mathrm{S}$ group were emerged in defining and identifying skills: $\mathrm{F}(1,63)=14.60, \boldsymbol{p}<001$, and $\mathrm{F}(1,63)=16.22, \boldsymbol{p}<.001$, respectively. However, no significant differences were found in the formulation and designing skills: $F(1,63)$ $=2.09, \boldsymbol{p}>.05$, and $\mathrm{F}(1,63)=1.56, \boldsymbol{p}>.05$, respectively. Table 2 presents the means and standard deviations for the $R L T$.

\section{The correlations between RL and AGM}

The third purpose of the study was to investigate the correlations between the RL skills (defining, identifying, formulating, designing) and Achievement Goal Motivational components (mastery-approach, performance-approach, mastery-avoidance and performance-avoidance) which are revealed in each of OLCs, by using the Pearson Test. This analyze has been emphasize the "identifying a research problem" as a RL skill which has a strong correlations with AGM components in both OLCs. For example, at the OLC+M this skill was correlated with the performance-avoidance $(\mathrm{r}=.25, \boldsymbol{p}<.05)$, and at the OLC+S it was significantly correlated with the mastery-approach $(\mathrm{r}=.253, \boldsymbol{p}$ $<.05)$. The additional significant correlation, which has been found at the OLC+M, emerged between the "designing a research" process and the mastery-approach ( $\mathrm{r}=$ $.293, \boldsymbol{p}<.05)$. The other correlations were not found within this analysis. Table 3 presents the correlation coefficients for means of the Achievement Goal Inventory and RLT in both groups.

\section{DiSCUSSION}

These outcomes shed new light on aspects of various types of scaffoldings of online PBL communities. In this section I first discuss possible reasons for differences in RL between the two OLCs. Secondly, I extend my findings to the correlation between these variables during the PBL process at the $\mathrm{OLC}+\mathrm{M}$ and the $\mathrm{OLC}+\mathrm{S}$.

\section{The effects of PBL on Achievement Goal Motivation}

The latest studies (Barber et al., 2015; Daradoumis et al., 2012) highlight the importance of the extensive use of different types of guidance within the PBL process. According to the literature (Franklin et al., 2015; Lee \& Tan, 2010; Hung \& Chen, 2001), all types of scaffoldings are necessary for increasing motivation, achieving the learning goals both increase a value for the 
learners' willingness to share their knowledge, to collaborate in the strategies, and to participate in reflective discussions. While the explicit moderator based instructions and scaffoldings embody enormous potential for the learners' knowledge construction and self-regulated learning, the social-based scaffolding is described as a powerful engine for constructivist collaborative guidance. Despite the facts mentioned in the literature, the current study doesn't show the significant effects of different scaffolding types on goal-based motivation. These findings lead to the suspicion that problem-based learning often tends to generate motivation in online communities in their various forms, interactive patterns, and learning scaffoldings. Further to this claim, it is recommended to examine additional online interactive environments that will assist in improving the aforementioned AGM components among adult students.

\section{The effects of PBL on Research Literacy skills}

The latest literature (Savery, 2015; Strobel \& Barneveld, 2009) defines PBL as a learner-centered instructional approach that empowers learners to conduct research, integrate theory and practice, and develop viable solutions to defined problems. The current study investigates the use of PBL in creating an up-to-date approach. The current results offer insight into the qualities of OLC+S, which showed significantly greater assimilation of Research Literacy in two of the four skills: defining and identifying a research problem. Controversy in the literature remains regarding the effects of PBL on investigating skills and critical thinking development. For example, Strobel \& Barneveld (2009) claim that such type of learning, which is accompanied by external directions of classmates, explicit milestones, and which co-supports students' prompts and performance, is suitable for basic learning strategies (such as organizing and retrieving separate pieces of information or analyzing authentic problems). These findings lead to the conclusion that in the area of Research Literacy, the OLC+S provides support that enables the enhancement of these basic research skills, such as defining and identifying a research problem, more than it supports advanced skills such as formulating an appropriate research question, and designing a method.

\section{Social and Direct Scaffoldings in OLCs during PBL}

My working assumption was that the participants' ability to create social interactions in OLCs and to encourage classmates to participate in different learning discussions indicating a high level of learning motivation, and this has been demonstrated partially. The social scaffoldings correlate positively with the mastery approach component of the Achievement Goal Motivation in two of four forums: identifying the research problem and designing the research process. This can be interpreted in accordance with researchers (Lim et al., 2011; Leahy \& Twomey, 2005) who claim that the PBL environments should emphasize motivational aspects of learning and goalachievement patterns in order to improve critical high order thinking (e.g. identifying research problem), and the actual practical skills (e.g. designing research process). His analysis leads to the conclusion that the motivational aspects of the community-based learning depends on heightened levels of interaction and on harmonization of social interactions and collaborated online learning. A prominent conclusion emerging from these findings is that an Online Community with social scaffoldings may support the improvement of motivational aspects among students. This conclusion points to the need to examine other emotional aspects of learners in online communities with an emphasis on knowledge collaboration and rich social interaction.

\section{CONCLUSIONS AND IMPLICATIONS}

On the theoretical level, this study offers important insight into evaluating PBL communication with different kinds of scaffolding as AGM components. On the practical level, this study provides perspective on an innovative method of assimilating the link between Research Literacy 
and pedagogy that has not been included in previous studies. Based on those findings, I suggest that there be future studies to expand and explore this approach with different student populations by focusing on PBL methods and their influence upon the professional development of students and practitioners in the education field. Finally, my recommendation is to delve deeper into this fascinating field, which emphasizes the importance of different kinds of interactions and centers of power that are passed on from teacher to student, through different intervention methods and different fields of knowledge in higher education in general, and in teacher training institutions in particular.

\begin{tabular}{|c|c|c|c|c|}
\hline Score & $\begin{array}{c}4 \\
\text { Answer contains } \\
\text { conceptual and } \\
\text { procedural } \\
\text { elements }\end{array}$ & $\begin{array}{c}3 \\
\text { Conceptual } \\
\text { answer }\end{array}$ & $\begin{array}{c}2 \\
\text { Procedural } \\
\text { answer }\end{array}$ & $\begin{array}{c}1 \\
\text { Partial answer }\end{array}$ \\
\hline Description & $\begin{array}{l}\text { The participant } \\
\text { knows the } \\
\text { theoretical and } \\
\text { practical } \\
\text { influences of this } \\
\text { issue }\end{array}$ & $\begin{array}{l}\text { The participant } \\
\text { knows the } \\
\text { theoretical } \\
\text { influences of this } \\
\text { issue }\end{array}$ & $\begin{array}{l}\text { The participant } \\
\text { knows how to } \\
\text { deal with this } \\
\text { issue }\end{array}$ & $\begin{array}{c}\text { The participant's } \\
\text { knowledge of } \\
\text { this issue is } \\
\text { partial }\end{array}$ \\
\hline Identifying & $\begin{array}{l}\text { This problem is } \\
\text { familiar to me } \\
\text { because as a } \\
\text { beginning teacher } \\
\text { I am in a } \\
\text { situation in } \\
\text { which the types } \\
\text { of conversation I } \\
\text { create in my } \\
\text { lessons impacts } \\
\text { the both the } \\
\text { social quality and } \\
\text { the level of } \\
\text { empathy in the } \\
\text { interactions } \\
\text { among the pupils }\end{array}$ & $\begin{array}{l}\text { This issue has } \\
\text { become familiar } \\
\text { to me since I } \\
\text { transferred from } \\
\text { early childhood } \\
\text { education to } \\
\text { community } \\
\text { education in } \\
\text { which there is a } \\
\text { strong emphasis } \\
\text { on the quality of } \\
\text { life in the school. }\end{array}$ & $\begin{array}{l}\text { It is possible to } \\
\text { identify those } \\
\text { values such as } \\
\text { listening, } \\
\text { dialogue, and } \\
\text { respectful } \\
\text { interpersonal } \\
\text { relations cause a } \\
\text { reduction in } \\
\text { violence. }\end{array}$ & $\begin{array}{l}\text { It is possible to } \\
\text { identify this } \\
\text { phenomenon in } \\
\text { many places. }\end{array}$ \\
\hline Defining & $\begin{array}{l}\text { The difficulty in } \\
\text { the research } \\
\text { stems from the } \\
\text { lack of awareness } \\
\text { on the part of } \\
\text { school staff, } \\
\text { particularly home } \\
\text { room teachers, } \\
\text { regarding the } \\
\text { strength of the } \\
\text { connection }\end{array}$ & $\begin{array}{l}\text { Currently many } \\
\text { researchers see } \\
\text { classroom climate } \\
\text { as a factor which } \\
\text { influences social } \\
\text { processes and a } \\
\text { sense of } \\
\text { belonging. }\end{array}$ & $\begin{array}{l}\text { Teachers do not } \\
\text { associate the } \\
\text { school quality of } \\
\text { life with social } \\
\text { skills. }\end{array}$ & $\begin{array}{l}\text { Teachers aren't } \\
\text { aware of this } \\
\text { problem. }\end{array}$ \\
\hline
\end{tabular}


International Journal of Education (IJE) Vol.6, No.4, December 2018

\begin{tabular}{|c|c|c|c|c|}
\hline & $\begin{array}{l}\text { between school } \\
\text { climate and } \\
\text { interactions } \\
\text { between pupils. } \\
\text { Examining the } \\
\text { school climate } \\
\text { variables and the } \\
\text { relationship } \\
\text { between them } \\
\text { and social skills } \\
\text { helps to explain } \\
\text { the influence of } \\
\text { school climate on } \\
\text { the pupils' social } \\
\text { competence. }\end{array}$ & & & \\
\hline Formulating & $\begin{array}{l}\text { An appropriate } \\
\text { research question } \\
\text { for this study } \\
\text { should refer to } \\
\text { the relationship } \\
\text { between school } \\
\text { climate and } \\
\text { students' social } \\
\text { skills. For } \\
\text { example, what is } \\
\text { the impact of } \\
\text { school climate on } \\
\text { each of the social } \\
\text { skills of the } \\
\text { learners. }\end{array}$ & $\begin{array}{l}\text { What is the } \\
\text { quality of the } \\
\text { relationship } \\
\text { between school } \\
\text { climate and the } \\
\text { social skills of the } \\
\text { students in } \\
\text { different streams } \\
\text { of education? }\end{array}$ & $\begin{array}{l}\text { Is there a link } \\
\text { between the } \\
\text { quality of school } \\
\text { life and students' } \\
\text { social skills? }\end{array}$ & $\begin{array}{l}\text { What is the } \\
\text { quality of the } \\
\text { school climate? }\end{array}$ \\
\hline Design & $\begin{array}{l}\text { The added value } \\
\text { of my proposed } \\
\text { research process } \\
\text { is the ability to } \\
\text { test the quality of } \\
\text { school life and its } \\
\text { relationship to } \\
\text { multiple indices } \\
\text { of social skills. }\end{array}$ & $\begin{array}{l}\text { The added value } \\
\text { of my proposed } \\
\text { research process } \\
\text { is to identify the } \\
\text { unique } \\
\text { contribution of } \\
\text { quality of life to } \\
\text { these measures } \\
\text { each of them } \\
\text { separately and all } \\
\text { together }\end{array}$ & $\begin{array}{l}\text { The research } \\
\text { tool I have } \\
\text { proposed is } \\
\text { designed to } \\
\text { examine the } \\
\text { relationship } \\
\text { between school } \\
\text { quality of life } \\
\text { and the students' } \\
\text { social skills }\end{array}$ & $\begin{array}{l}\text { I have proposed } \\
\text { a research } \\
\text { process which is } \\
\text { based on } \\
\text { observations. }\end{array}$ \\
\hline
\end{tabular}

Figure 1:

A Scoring Scheme of the Research Literacy Task (RLT)

(Gutman \& Genser, 2017) 
Table 1:

Means and SD of Achievement Goal Motivation (AGM), by testing occasion (pre, post) and groups $(\mathrm{OLC}+\mathrm{M}, \mathrm{OLC}+\mathrm{S})$

\begin{tabular}{|c|c|c|c|c|}
\hline & \multicolumn{2}{|c|}{$\begin{array}{c}\text { OLC+MI } \\
(N=3 I)\end{array}$} & \multicolumn{2}{|c|}{$\begin{array}{l}\text { OLC+S } \\
(N=34)\end{array}$} \\
\hline & Pre & Post & Pre & Post \\
\hline \multicolumn{5}{|l|}{ mastery } \\
\hline \multicolumn{5}{|c|}{ approach } \\
\hline $\mathbf{M}$ & 2.83 & 2.99 & 2.78 & 3.04 \\
\hline SD & .52 & -45 & .54 & -49 \\
\hline \multicolumn{5}{|c|}{ performance } \\
\hline \multicolumn{5}{|c|}{ approach } \\
\hline $\mathbf{M}$ & 2.77 & 2.97 & 2.83 & 3.09 \\
\hline SD & 61 & -45 & .54 & -44 \\
\hline \multicolumn{5}{|l|}{ mastery } \\
\hline \multicolumn{5}{|c|}{ avoidance } \\
\hline $\mathbf{M I}$ & 2.72 & 2.87 & 2.68 & 2.91 \\
\hline SD & .56 & .52 & .56 & -44 \\
\hline \multicolumn{5}{|c|}{ Performance } \\
\hline \multicolumn{5}{|c|}{ Avoidance } \\
\hline $\mathbf{M}$ & 2.72 & 2.88 & 2.68 & 3.02 \\
\hline SD & -68 & -44 & .54 & -46 \\
\hline
\end{tabular}

Table 2:

Means and SD of Research Literacy Task (RLT), by groups

\begin{tabular}{rcc}
\hline & $\begin{array}{c}\text { OLC+M } \\
(N=31)\end{array}$ & $\begin{array}{r}\text { OLC+S } \\
(N=34)\end{array}$ \\
\hline Identify & 2.29 & 2.0 \\
$\mathbf{M}$ & .98 & .95 \\
\hline SD & 3.26 & \\
Define & .85 & 2.29 \\
SD & & 1.14 \\
\hline Formulate & 2.77 & \\
M & 1.11 & 2.41 \\
SD & & 1.21 \\
\hline Design & 2.80 & \\
M & .98 & 2.44 \\
SD & & .051 \\
\hline
\end{tabular}


Table 3:

Correlation Coefficients for both types of scaffoldings and Achievement Goal Motivation Inventory in All Online Forums

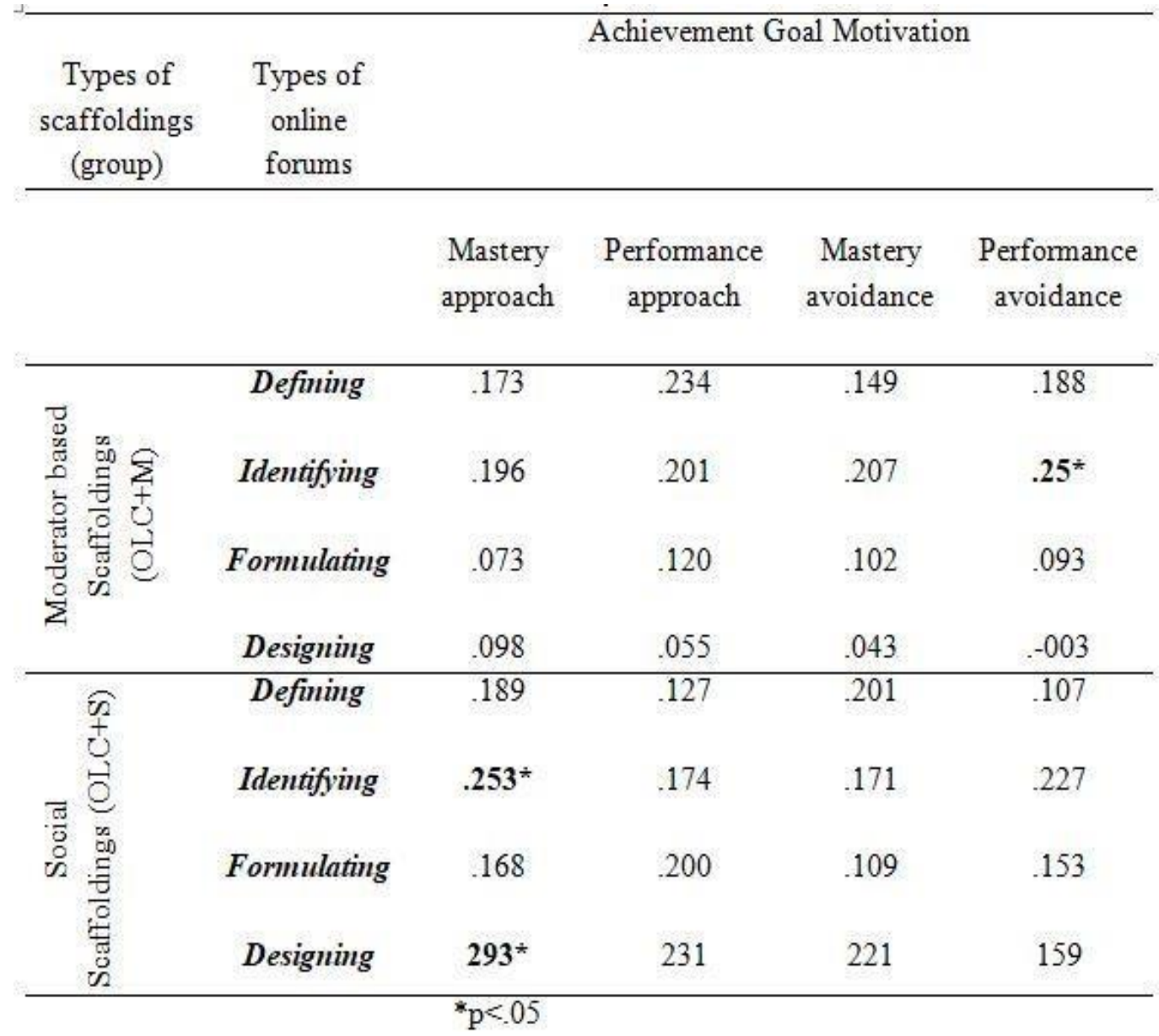

\section{REFERENCES}

[1] Abdelaziz, H. A. (2014). The Interaction between the Source and the Level of Feedback in Blended Courses and Its Impact on Achievement and Self-efficacy. Journal of Communication and Computer, 11, 423-440.

[2] Adesope, O. O., Zhou, M., \& Nesbit, J. C. (2015). Achievement Goal Orientations and SelfReported Study Strategies as Predictors of Online Studying Activities. Journal of Educational Computing Research, 53(3), 436-458.

[3] Barber, W., King, S., \& Buchanan, S. (2015). Problem Based Learning and Authentic Assessment in Digital Pedagogy: Embracing the Role of Collaborative Communities. Electronic Journal of $e$ Learning, 13(2).

[4] Bickhard, M. H. (2013). Scaffolding and self-scaffolding: Central aspects of development. LT Winegar, Sc]. Valsiner (Eds), Chz'ldreri'sd U, 610, 33-52.

[5] Daradoumis, T., Caballé, S., Perez, A. A. J., \& Xhafa, F. (Eds.). (2012). Technology-enhanced systems and tools for collaborative learning scaffolding (Vol. 350). Springer Science \& Business Media. 
[6] Duffy, M. C., \& Azevedo, R. (2015). Motivation matters: Interactions between achievement goals and agent scaffolding for self-regulated learning within an intelligent tutoring system. Computers in Human Behavior, 52, 338-348.

[7] Elliot, A., \& Church, M. (1997). A hierarchical model of approach and avoidance achievement motivation. Journal of Personality and Social Psychology, 72, 218-232.

[8] Elliot, A. J., \& McGregor, H. A. (2001). A $2 \times 2$ achievement goal framework. Journal of personality and social psychology, 80(3), 501.

[9] Elliot, A. J., \& Murayama, K. (2008). On the measurement of achievement goals: Critique, illustration, and application. Journal of Educational Psychology, 100(3), 613.

[10]Franklin, B. M., Xiang, L., Collett, J. A., Rhoads, M. K. \& Osborn, J.L. (2015). Open problembased instruction impacts understanding of physiological concepts differently in undergraduate students. Advances in Physiology Education, 39, 327-334.

[11]Gutman, M. (2017). Facilitating pre-service teachers to develop Regulation of Cognition with Learning Management System. Educational Media International, 54(3), 199214.

[12] Gutman, M., \& Genser, L. (2017). How pre-service teachers internalize the link between research literacy and pedagogy. Educational Media International, 54(5), 63-74.

[13]Harun, N. F., Yusof, K. M., Jamaludin, M. Z., \& Hassan, S. A. H. S. (2012). Motivation in problem-based learning implementation. Procedia-Social and Behavioral Sciences, 56, 233-242.

[14]Hung, D. W., \& Chen, D. T. (2001). Situated cognition, vygotskian thought and learning from the communities of practice perspective: Implications for the design of web-based e-learning. Educational Media International, 38, 3-12.

[15]Leahy, M., \& Twomey, D. (2005). Using web design with pre-service teachers as a means of creating a collaborative learning environment. Educational Media International, 42, 143-151.

[16]Lee, C. C., \& Tan, S. C. (2010). Scaffolding writing using feedback in students' graphic organizers-novice writers' relevance of ideas and cognitive loads. Educational Media International, 47(2), 135-152.

[17]Lim, C. P., Chai, C. S., \& Churchill, D. (2011). A framework for developing pre-service teachers' competencies in using technologies to enhance teaching and learning. Educational Media International, 48, 69-83.

[18] Palincsar, A. S., Anderson, C, \& David, Y. M. (1993). Pursuing scientific literacy in the middle grades through collaborative problem solving. The Elementary School journal, 93, 643-658.

[19] Savery, J. R. (2015). Overview of problem-based learning: Definitions and distinctions. Essential Readings in Problem-Based Learning: Exploring and Extending the Legacy of Howard S. Barrows, 5-15.

[20]Strobel, J. \& Barneveld, A. (2009). When is PBL more effective? A meta-synthesis of metaanalyses comparing PBL to conventional classrooms. Interdisciplinary Journal of Problem Based Learning, 3(4), 2009.

[21] Tuckman, B. W., \& Harper, B. E. (2012). Conducting educational research. Rowman \& Littlefield Publishers.

[22] Wolters, C. A. (2004). Advancing Achievement Goal Theory: Using Goal Structures and Goal Orientations to Predict Students' Motivation, Cognition, and Achievement. Journal of educational psychology, 96(2), 236.

[23]Zhu, E., \& Baylen, D. M. (2005). From learning community to community learning: pedagogy, technology and interactivity. Educational Media International,

42(3), 251-268. 